University of Nebraska - Lincoln

DigitalCommons@University of Nebraska - Lincoln

Agronomy \& Horticulture -- Faculty Publications

Agronomy and Horticulture Department

$1-1981$

\title{
Heritability Estimates for Height, Color, Erectness, Leafiness, and Vigor in Indiangrass
}

\author{
K. P. Vogel \\ United States Department of Agrculture, kvogel1@unl.edu \\ Herman J. Gorz \\ United States Department of Agrculture \\ Francis A. Haskins \\ University of Nebraska-Lincoln, fhaskins@neb.rr.com
}

Follow this and additional works at: https://digitalcommons.unl.edu/agronomyfacpub

Part of the Plant Sciences Commons

Vogel, K. P.; Gorz, Herman J.; and Haskins, Francis A., "Heritability Estimates for Height, Color, Erectness, Leafiness, and Vigor in Indiangrass" (1981). Agronomy \& Horticulture -- Faculty Publications. 245.

https://digitalcommons.unl.edu/agronomyfacpub/245

This Article is brought to you for free and open access by the Agronomy and Horticulture Department at DigitalCommons@University of Nebraska - Lincoln. It has been accepted for inclusion in Agronomy \& Horticulture -Faculty Publications by an authorized administrator of DigitalCommons@University of Nebraska - Lincoln. 


\title{
Heritability Estimates for Height, Color, Erectness, Leafiness, and Vigor in Indiangrass ${ }^{1}$
}

\author{
K.P. Vogel, H.J. Gorz, and F.A. Haskins ${ }^{2}$
}

\begin{abstract}
The purpose of this study was to determine heritability estimates for plant height, leaf color, erectness, leafiness, and vigor and the correlation of these traits with one another and with forage yield, forage in vitro dry matter digestibility (IVDMD), and forage crude protein content for two indiangrass [Sorghastrum nutans (L.) Nash] populations taken from the cultivars 'Holt' and 'Oto' both of which have broad genetic bases. Narrow sense heritability estimates were obtained by using parent-progeny regression and by using variance components from the analyses of variance of half-sib families. Broad sense heritability estimates were obtained using variance components from the analyses of variance of replicated parental clones. Narrow sense heritability estimates averaged over all methods and both populations were $0.75,0.59,0.48$, 0.36 , and 0.50 for plant height, leaf color, erectness, leafiness, and vigor, respectively. Simple correlations of plant height, leafiness, and vigor with forage yield range from 0.24 to 0.58 , and all were significant at the 0.01 level. Correlations of color and erectness with yield were very low or nonsignificant. Absolute values of correlation coefficients of IVDMD and protein content with the five traits evaluated were in general very low. These results indicate that vigor or leafiness scores or plant height may be useful in selecting for yield in indiangrass, but leaf color or erectness would have little value in selecting for yield. None of the five traits would be very useful in selecting for IVDMD or protein.
\end{abstract}

Additional index words: Sorghastrum nutans, Quantitave genetics, Forage yield, Forage quality.

$I^{N}$ NDIANGRASS [Sorghastrum nutans (L.) Nash] is a warm-season, cross-pollinated grass native to the prairies and plains of the United States. In a previous paper, we reported heritability estimates for heading date, forage yield, forage in vitro dry matter digestibility (IVDMD), and forage protein content for indiangrass (Vogel et al., 1981). Narrow sense heritability estimates for forage yield, IVDMD, and protein for two indiangrass populations averaged $0.43,0.42$, and 0.50 , respectively. $\mathrm{N}_{3}, \ldots-v_{\text {s }}$ sense heritability estimates for heading date were larger. In addition to variation in heading date and forage yield, considerable variation also was observed in plant height, leaf color, plant erectness, leafiness, and vigor. The purpose of this study was to determine heritability estimates for the latter five traits and the correlation of these traits with one another and with forage yield, forage IVDMD, and forage protein content.

\section{MATERIALS AND METHODS}

The indiangrass populations used in this study, the experimental design, field plot and laboratory procedures, and the statistical methods used to obtain heritability estimates for forage yield, IVDMD, protein, and heading date were reported previously (Vogel et al., 1980, 1981). On the heading date, the plants were measured for plant height $(\mathrm{cm})$ and were scored for color, erectness, leafiness, and vigor. The scoring system used was a 1 to 4 scale as follows for the traits rated: erectness $l=$ erect to $4=$ decumbent; leaf color, $1=$ green, $2=$ greenish blue, $3=$ bluish-green, $4=$ blue; leafiness, $1=$ leafy to $4=$ stemmy; vigor, $1=$ excellent to $4=$ very poor. Heritability estimates were obtained by using procedures described by Vogel et al. (1981). Simple correlations among all traits were determined for both the parents and progenies of both populations on an individual plant basis. Thirty-six Holt families, 147 sets of Oto parents, and 146 sets of Oto progenies were used in the statistical analyses for 1976. In 1977, data were collected from only 30 Oto families that had high yields in 1976 .

\section{RESULTS AND DISGUSSION}

In 1976, there were significant differences among the parents and progenies of both populations for plant height, leaf color, erectness, leafiness, and vigor (Table 1). For 1976 and 1977, there were significant differences among the parental clones evaluated for height, color, and erectness while among the progeny were was a significant difference only for erectness. The effect of years was significant for height and vigor among the progeny. The genotype $\times$ year interaction was significant for vigor of the parents. All other year and genotype $\times$ year effects

'Contribution of the Dep. of Agronomy, Univ. of Nebraska, and ARS/USDA. Published as Paper No. 5887, Journal Series, Nebraska Agric. Exp. Stn. Received 10 Nov. 1980.

'Research agronomist, ARS/USDA; supervisory research geneticist, ARS/USDA; and George Holmes professor of agronomy, Univ. of Nebraska, Lincoln, NE 68583. 
Table 1. Means and heritability estimates for indiangrass parental clones and their progenies.

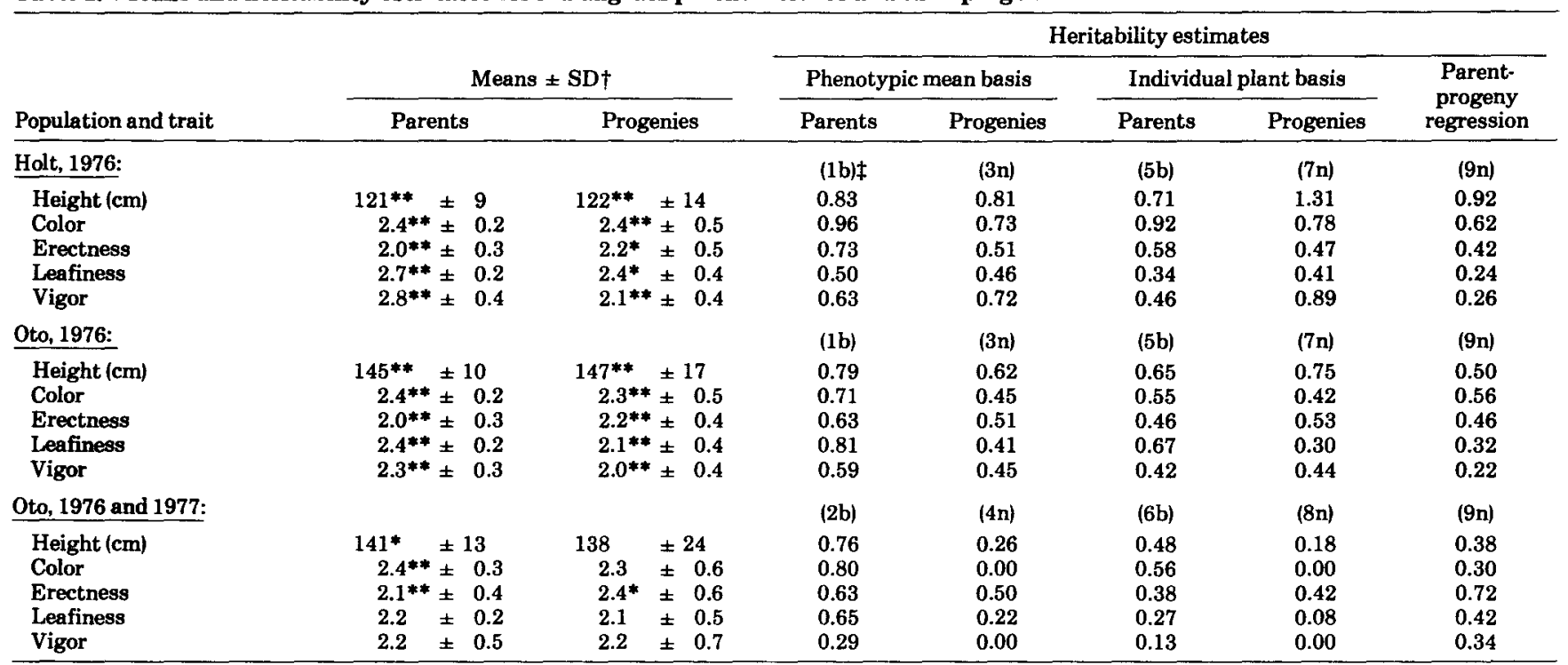

*,** Indicates significance of the mean squares for genotypes in the analyses of variance at the 0.05 and 0.01 levels of probability, respectively.

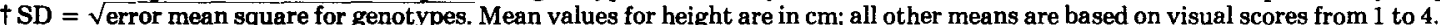

$\ddagger$ Numbers in parentheses refer to the equations, listed in Table 2 of Vogel et al. (1981) that were used to determine the heritability estimates; b indicates broad-sense and $n$ indicates narrow-sense estimates.

Table 2. Simple correlations among traits for Holt $\uparrow$ and Oto $\dagger$ parental clones (upper values) and their progenies (lower values) in 1976.

\begin{tabular}{|c|c|c|c|c|c|c|c|c|c|}
\hline Traits & Yield & IVDMD & Protein & Date & Height & Color & Erectness & Leafiness $\$$ & Vigor $¥$ \\
\hline Yield & & $\begin{array}{l}-0.21 \\
-0.08\end{array}$ & $\begin{array}{l}-0.29 \\
-0.28^{* *}\end{array}$ & $\begin{array}{l}0.28^{*} \\
0.42^{* *}\end{array}$ & $\begin{array}{l}0.35^{* *} \\
0.58^{* *}\end{array}$ & $\begin{array}{l}-0.12 \\
-0.03\end{array}$ & $\begin{array}{l}0.04 \\
0.13^{* *}\end{array}$ & $\begin{array}{l}0.43^{* *} \\
0.30^{* *}\end{array}$ & $\begin{array}{l}0.57^{* *} \\
0.48^{* *}\end{array}$ \\
\hline IVDMD & $\begin{array}{l}0.00 \\
0.03\end{array}$ & & $\begin{array}{l}0.44^{* *} \\
0.48^{* *}\end{array}$ & $\begin{array}{l}-0.42^{* *} \\
-0.21^{* *}\end{array}$ & $\begin{array}{l}-0.26^{*} \\
-0.19^{* *}\end{array}$ & $\begin{array}{l}0.12 \\
0.08\end{array}$ & $\begin{array}{l}-0.17 \\
-0.09\end{array}$ & $\begin{array}{l}0.00 \\
0.01\end{array}$ & $\begin{array}{r}-0.12 \\
0.01\end{array}$ \\
\hline Protein & $\begin{array}{l}-0.09 \\
-0.10^{* *}\end{array}$ & $\begin{array}{l}0.39 * * \\
0.43^{* *}\end{array}$ & & $\begin{array}{l}-0.44^{* *} \\
-0.39 * *\end{array}$ & $\begin{array}{l}-0.27^{*} \\
-0.33^{* *}\end{array}$ & $\begin{array}{l}0.23^{*} \\
0.07\end{array}$ & $\begin{array}{l}-0.15 \\
-0.21 * *\end{array}$ & $\begin{array}{l}-0.17 \\
-0.14^{*}\end{array}$ & $\begin{array}{r}-0.16 \\
0.03\end{array}$ \\
\hline Date & $\begin{array}{l}0.14 \\
0.13\end{array}$ & $\begin{array}{l}-0.14^{*} \\
-0.07^{*}\end{array}$ & $\begin{array}{l}-0.31^{* *} \\
-0.20^{* *}\end{array}$ & & $\begin{array}{l}0.51^{* *} \\
0.34^{* *}\end{array}$ & $\begin{array}{l}-0.37^{* *} \\
-0.28^{* *}\end{array}$ & $\begin{array}{l}0.45^{* *} \\
0.48 * *\end{array}$ & $\begin{array}{l}0.10 \\
0.34 * *\end{array}$ & $\begin{array}{l}-0.10 \\
-0.20 *\end{array}$ \\
\hline Height & $\begin{array}{l}0.24^{* *} \\
0.30^{* *}\end{array}$ & $\begin{array}{l}-0.18^{* *} \\
-0.07^{*}\end{array}$ & $\begin{array}{l}-0.31^{* *} \\
-0.19^{* *}\end{array}$ & $\begin{array}{l}0.39^{* *} \\
0.09^{* *}\end{array}$ & & $\begin{array}{r}-0.03 \\
0.02\end{array}$ & $\begin{array}{c}0.11 \\
-0.22^{* *}\end{array}$ & $\begin{array}{r}-0.01 \\
0.02\end{array}$ & $\begin{array}{l}0.41^{* *} \\
0.60^{* *}\end{array}$ \\
\hline Color & $\begin{array}{l}0.04 \\
0.04\end{array}$ & $\begin{array}{r}0.02 \\
-0.03\end{array}$ & $\begin{array}{l}0.07 \\
0.00\end{array}$ & $\begin{array}{l}-0.15^{* *} \\
-0.06^{*}\end{array}$ & $\begin{array}{c}-0.13^{*} \\
0.10\end{array}$ & & $\begin{array}{l}-0.36^{* *} \\
-0.18^{* *}\end{array}$ & $\begin{array}{l}0.33^{* *} \\
0.22^{* *}\end{array}$ & $\begin{array}{l}-0.23^{*} \\
-0.21 * *\end{array}$ \\
\hline Erectness & $\begin{array}{l}0.07 \\
0.21 * *\end{array}$ & $\begin{array}{l}-0.08 \\
-0.02\end{array}$ & $\begin{array}{r}-0.11 \\
0.01\end{array}$ & $\begin{array}{l}0.24^{* *} \\
0.20^{* *}\end{array}$ & $\begin{array}{l}-0.16^{* *} \\
-0.32^{* *}\end{array}$ & $\begin{array}{l}-0.09 \\
-0.02\end{array}$ & & $\begin{array}{l}-0.02 \\
-0.39 * *\end{array}$ & $\begin{array}{l}0.33^{* *} \\
0.39 * *\end{array}$ \\
\hline Leafinessł & $\begin{array}{l}0.35^{* *} \\
0.25^{* *}\end{array}$ & $\begin{array}{l}0.13^{*} \\
0.10^{* *}\end{array}$ & $\begin{array}{r}-0.02 \\
0.05\end{array}$ & $\begin{array}{l}0.23^{* *} \\
0.18^{* *}\end{array}$ & $\begin{array}{c}0.04 \\
-0.08^{* *}\end{array}$ & $\begin{array}{l}0.09 \\
0.16\end{array}$ & $\begin{array}{l}-0.02 \\
-0.11^{* *}\end{array}$ & & $\begin{array}{l}0.26^{*} \\
0.06\end{array}$ \\
\hline Vigor & $\begin{array}{l}0.50^{* *} \\
0.53^{* *}\end{array}$ & $\begin{array}{l}-0.05 \\
-0.03\end{array}$ & $\begin{array}{l}-0.17^{* *} \\
-0.10^{* *}\end{array}$ & $\begin{array}{c}0.01 \\
-0.10^{* *}\end{array}$ & $\begin{array}{l}0.48^{* *} \\
0.67^{* *}\end{array}$ & $\begin{array}{l}0.05 \\
0.01\end{array}$ & $\begin{array}{l}0.08 \\
0.16^{* *}\end{array}$ & $\begin{array}{l}0.36^{* *} \\
0.17^{* *}\end{array}$ & \\
\hline
\end{tabular}

*** Indicates significance at the 0.05 and the 0.01 levels of probability, respectively.

$\dagger$ Holt values are above the diagonal and $O$ to values are below it.

$\ddagger$ The algebraic signs of all the correlation coefficients involving yield, IVDMD, protein, date and height were changed to reflect direct relationships since a score of 1 indicated superiority and a score of 4 indicated inferiority.

were nonsignificant. The results demonstrate that there are significant genetic differences among indiangrass plants for height, leaf color, erectness, leafiness, and vigor. The Oto plants tended to be taller and less leafy than the Holt plants (Table 1). Both populations had similar means for the other traits.

On a phenotypic mean basis, broad sense heritability estimates determined from parental clones were only slightly higher than narrow sense heritability estimates determined from half-sib progenies (Table 1). The same relationship existed for heritabilities determined on an individual plant basis, although narrow sense heritabilities were larger than broad sense estimates for plant height and erectness in 1976 . These results indicate that most of the genetic variation within populations for these traits is additive. Heritability estimates determined by parent-progeny regression were generally of the same magnitude or slightly lower than the narrow sense estimates determined by variance component analyses in 1976 for both populations.

Some of the narrow sense heritability estimates determined by variance component analyses for the Oto families evaluated in 1976 and 1977 were zero or very small because of large environmental variance components, while heritability estimates determined by parent-progeny regression were all 0.30 or larger.

Heritability estimates obtained from 1976 data were more reliable than those obtained for the 2-year period of 1976 and 1977 since more genotypes were evaluated and 
the genotype $x$ year effect was significant only for vigor for the parents. Narrow sense heritability estimates averaged over all methods and both populations were $0.75,0.59,0.48,0.36$, and 0.50 for plant height, leaf color, erectness, leafiness, and vigor, respectively. In calculating the averages, heritability values greater than 1 were given a value of 1 . These results indicate that in indiangrass, plant height was highly heritable while the heritability of leaf color was moderately high. The average heritability values for erectness, leafiness, and vigor were in the same range as those for forage yield, IVDMD, and protein (Vogel et al., 1981).

Simple correlations of plant height, leafiness, and vigor with forage yield ranged from 0.24 to 0.58 and all were significant at the 0.01 level of probability (Table 2). Correlations of color and erectness with yield were very low or nonsignificant. The absolute values of the correlation coefficients of IVDMD and protein with plant height, color, erectness, leafiness, and vigor were all 0.33 or lower. Height had low negative correlations with IVDMD and protein. Leaf color, erectness, leafiness, and vigor were generally not correlated with IVDMD and protein although the correlation coefficients varied among parents, progenies, and populations. Leafiness scores were probably not correlated with IVDMD and protein because stems and leaves of indiangrass have similar IVDMD and protein values throughout the growing season (Perry and Baltensperger, 1979). These results indicate that vigor and leafiness scores and plant height may be useful in selecting for yield in indiangrass, but that scoring for color or erectness would have little value in selecting for yield. None of the five traits would be very useful in selecting for IVDMD or protein. Height memsurements may be of value in selecting plants uniform in height for mechanical seed harvest. Vigor scores and height measurement made in a single year on established plants would be adequate for selection.

\section{REFERENCES}

Perry, L.J. Jr., and D.D. Baltensperger. 1979. Leaf and stem yields and forage quality of three $\mathrm{N}$-fertilized warm-season grasses. Agron. J$71: 355-358$.

Vogel, K.P., F.A. Haskins, and H.J. Gorz. 1980. Inflation of heritability estimates by environmental covariances. Crop Sci. 20:580-582.

,---- H.J. Gorz, and F.A. Haskins. 1981. Heritability estimates of forage yield, in vitro dry matter digestibility, protein content, and heading date in indiangrass. Crop Sci. 21:35-38. 